\title{
Influence of Sex on Haematological Response of Clarias gariepinus Juveniles Treated with Atrazine and Metalochlor
}

\section{Abstract}

A total of 180 Clarias gariepinus juveniles comprising of 90 male and female each, were exposed to different concentrations of combined atrazine and metolachlor $(0.00 \mathrm{mg} / \mathrm{L}$-control, $0.01,0.02,0.03,0.04$ and $0.05 \mathrm{mg} / \mathrm{L})$ for 14 days to assess the influence of sex on the response of the fish to this chemical under laboratory conditions. The result obtained revealed that the female fish in the control group had an increase value of haemoglobin $(\mathrm{Hb})$ than the male, while in the experimental group the values of $\mathrm{Hb}$ in male fish were consistently higher than the females. The comparative values of red blood cell (RBC) indicated that the female fish had higher values of RBC than the male in all concentrations of exposure. In packed cell volume (PCV), female fish were higher than the males. In assessment of male and female response to the toxicant under consideration, the values of white blood cells (WBC), neutrophils and monocytes increased significantly with increasing concentrations of the chemical with the female values higher than the males. Also, the values of lymphocytes, platelets, mean corpuscular volume (MCV) and mean corpuscular haemoglobin (MCH) in the exposed fish indicated a significant reduction, which was more noticeable in female than the male fish. However, mean corpuscular haemoglobin concentration (MCHC) values were within the same range for both sexes. Overall, it appears that the males were more responsive to the stress of chemical exposure than the females.

Keywords: Catfish; Sex; Toxicants; Blood; Aquatic systems; Water pollution; Atrazine; Metalochlor

Received: August 07, 2017; Accepted: August 11, 2017; Published: August 18,2017

\section{Introduction}

Water contamination has become an issue in recent times, causing a great damage to the aquatic ecosystems. Wastes generated by industries and homes ultimately find their way into the aquatic environment. Most of these water bodies have become polluted consequent of consistent discharge of these refuse into them and making it unfavourable for aquatic organism especially fish [1]. Fresh and marine water pollution by toxicants released from industrial discharge is a regular source of public health concern especially in urban centers [2]. These pollutants range from herbicides as runoffs from farms, to organic pollutants, such as polycyclic aromatic hydrocarbons from oil explorative activities, and heavy metals from industries [3]. The run offs from farms are a compound combination of a number of chemical components [4] and have high level of oxidant capability [5]. According to

\section{George ADI ${ }^{1}$ and Akinrotimi $O A^{2}$}

\author{
1 Department of Fisheries, Faculty of \\ Agriculture, Rivers State University of \\ Science and Technology, P.M.B. 5080, \\ Nkpolu-Oroworkwo, Port Harcourt, \\ Rivers State, Nigeria \\ 2 African Regional Aquaculture Center \\ of Nigerian Institute for Oceanography \\ and Marine Research, P.M.B.5122, Port \\ Harcourt, Rivers State, Nigeria
}

\section{Corresponding author: Akinrotimi OA}

ほ ojoakinrotimi@gmail.com

African Regional Aquaculture Center of Nigerian Institute for Oceanography and Marine Research, P.M.B.5122, Port Harcourt, Rivers State, Nigeria.

Tel: +2348065770699

Citation: George ADI, Akinrotimi OA (2017) Influence of Sex on Haematological Response of Clarias gariepinus Juveniles Treated with Atrazine and Metalochlor. Trends Green Chem. Vol. 3 No. 1:6 
physiology and health status of the organism under investigation $[11,12]$.

Numerous authors have reported the toxicity and haematological alterations in fish exposed to different chemicals in the laboratory [13-15]. Moreover, the use of hematological strategies in fisheries studies is developing rapidly, as it is very essential in toxicological research which bring about tracking and envisaging fitness situations of the fish $[16,17]$. In view that fish are closely related with the aqueous surroundings, the blood will bring to light some alterations inside the fish quickly than any physiological assessment parameters [18]. Contaminants which include herbicides, pesticide and industrial effluent are well-known to cause drastic changes in the haematological parameters of fish [19-21].

Evaluation of blood variables is a vital tool for assessment of fish physiological conditions $[22,23]$. Estimation of haematological indices for detection of chemical induced stress in the system of the fish is a common practice among fishery scientists. Fish blood parameters vary in different species which may be attributed to genetic variation, nutritional status, sex, age, and strain due to capture, handling and sampling procedures $[24,25]$. For this reason, it is essential to evaluate influence of sex on haematological parameters of fish, so as to ascertain its influence in the face of any stressor such as chemicals. The influence of sex factor is widely recognized in various diseases, but its molecular basis, particularly how sex-biased gender behave in response to toxico-pathological changes is poorly understood. Hence, this study focused on the influence of sex on haematological response of Clarias gariepinus juveniles treated with atrazine and metalochlor under laboratory conditions

\section{Material and Methods}

The experiment was conducted at the Toxicity laboratory in African Regional Aquaculture Centre, Aluu, Rivers State, Nigeria. One Hundred and eighty (180 juveniles) of $C$. gariepinus of (mean length $8.74 \pm 2.64 \mathrm{~cm}$ and mean weight $56.68 \pm 1.81 \mathrm{~g}$ ) comprising of 90 male and female fish each were procured from the center and taken to the laboratory where they were acclimatized for a period of seven days. After acclimatizing the fish to laboratory conditions, 10

fish were introduced individually into 18 , aquaria tanks of $1.5 \mathrm{~m}$ $\times 1 \mathrm{~m} \times 0.5 \mathrm{~m}$ dimension, containing 0.00 (control), 0.10, 0.20, $0.30,0.40$ and $0.50 \mathrm{mg} / \mathrm{L}$ of Delta Force (metalochlor/atrazine). Each treatment and control had three replicates and lasted for a total of 14 days. The solution for each concentration was replenished on daily basis, with freshly prepared solution of Delta Force (metalochlor/atrazine).

Haematological analysis methods as described by Blaxhall and Daisley [26] were used in the assessment of the various blood parameters or otherwise stated. Red blood cell (RBC) was analysed using haemocytometer; while the packed cell volume (PCV) was estimated using micro haematocrit tubes after centrifuging for five minutes. The hemoglobin content of the blood was evaluated by cyanomethaemoglobin method. The white blood cells (WBC) were determined using improved Neubauer counter. The values of thrombocytes were estimated using the Rees and Beeker method [27]. The differential counts (neutrophils, lymphocytes, eosinophils and monocytes) were assessed by dropping thoroughly mixed blood film on clean microscope slides and allowed to dry. The slides were then fixed in methanol and stained with leishman stain. The counting was done based on different cell types and recorded. The values of haematological indices were calculated using the method of Rusia and Sood [28].

$\mathrm{OCC}=\mathrm{Hb} \times 1.25$

$$
\begin{aligned}
& \mathrm{MCV}=\frac{H C T}{R B C} \times 10 \\
& \mathrm{MCH}=\frac{H b}{R B C} \times 10 \\
& \mathrm{MCHC}=\frac{H b}{P C V} \times 10
\end{aligned}
$$

Source: Seiverd [27]

Data obtained from the study were collated and analyzed using Microsoft excel statistical package.

\section{Results}

The results of the haematological parameters of male and female of C. gariepinus exposed to Atrazine and Metalochlor for 14 days are shown in Figures 1 to $\mathbf{1 1}$. The result on the Figure 1 indicates that the female $C$. gariepinus in the control group had an increase value of $\mathrm{Hb}$ than the male, while in the experimental group the values of $\mathrm{Hb}$ in male fish were consistently higher than the females (Figure 1). The comparative values of RBC revealed that the female fish had higher values of RBC than the male in all concentrations (Figure 2). In Figure 3; the values of PCV in female fish were higher than the male. In assessment of male and female response to the toxicant under consideration, the values of WBC, neutrophils and monocytes increased significantly

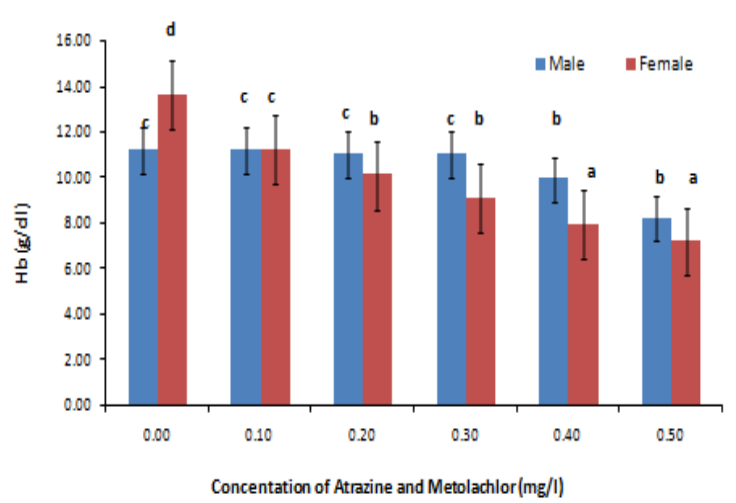

Bars with the different superscripts are significant $(p<0.05)$

Figure 1 Comparative values of Haemoglobin $(\mathrm{Hb})$ in $C$. goriepinus juveniles exposed to Atrazine and Metolachlor. 


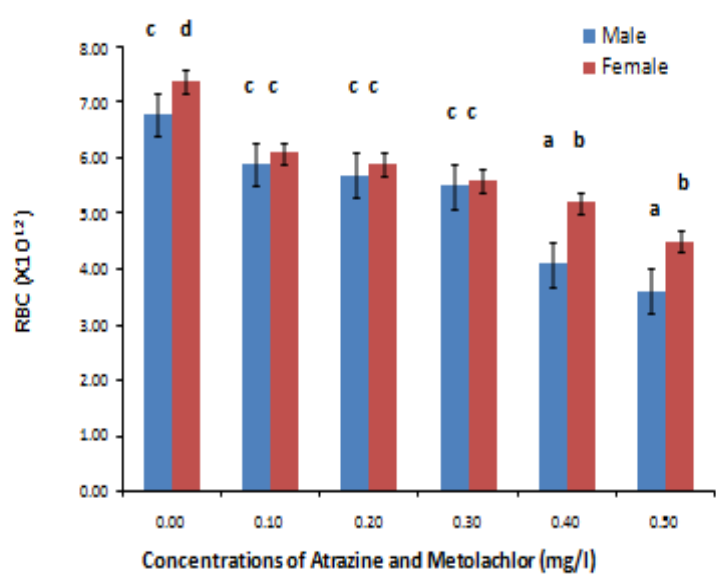

Bars with the different superscripts are significant $(p<0.05)$

Figure 2 Comparative values of Red Blood Cell in $C$. gariepinus juveniles exposed to Atrazine and Metolachlor.

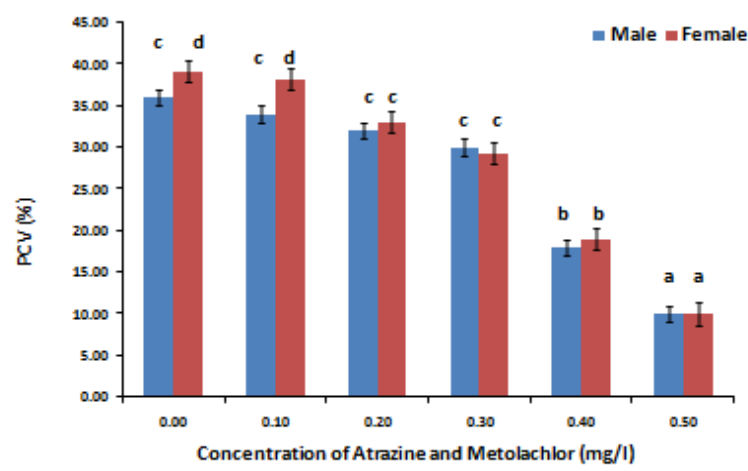

Bars with the different superscripts are significant $(p<0.05)$

Figure 3 Comparative values of Red Blood Cell in $C$. gariepinus juveniles exposed to Atrazine and Metolachlor.

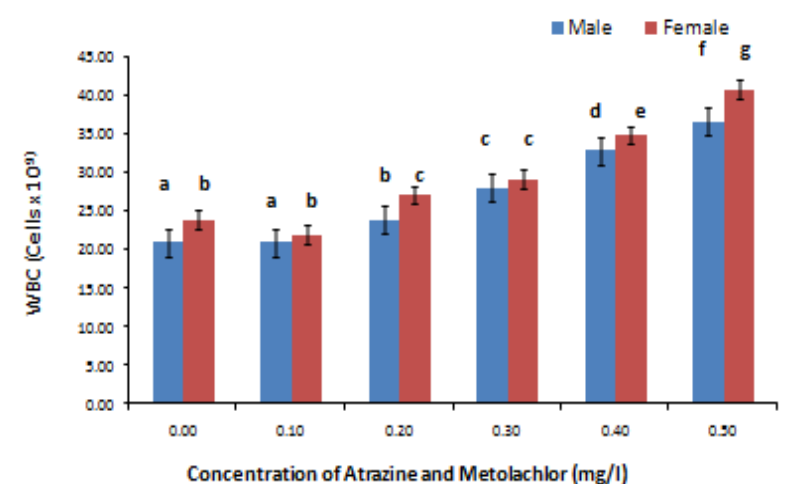

Bars with the different superscripts are significant $(p<0.05)$

Figure 4 Comparative White blood cell (WBC) values in C. goriepinus juveniles exposedto Atrazine and Metolachlor.

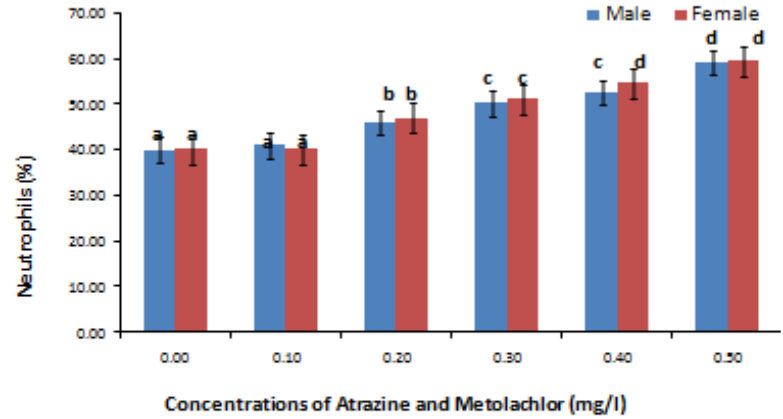

Bars with the different superscripts are significant $(p<0.05)$

Figure 5 Comparative Neutrophils values in C. goriepinus exposed to Atrazine and Metolachlor.

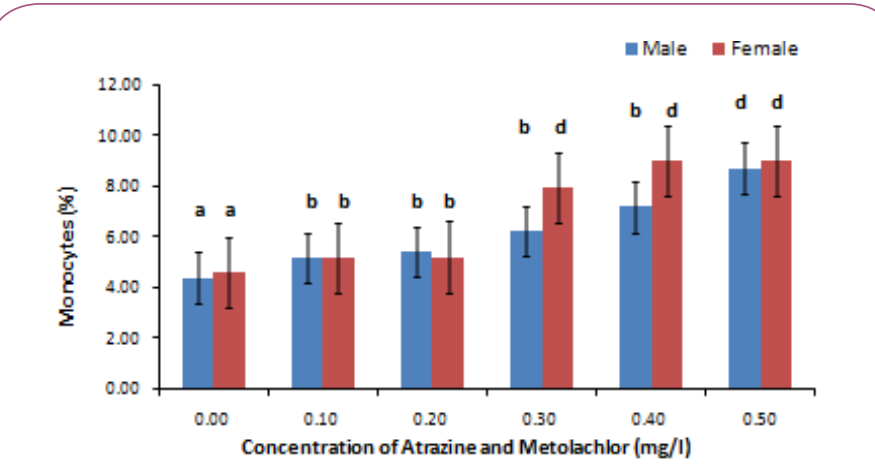

Bars with the different superscripts are significant $(p<0.05)$

Figure 6 Comparative values of Monocytes in Clarias goriepinus juveniles exposed to Atrazine and Metolachlor.

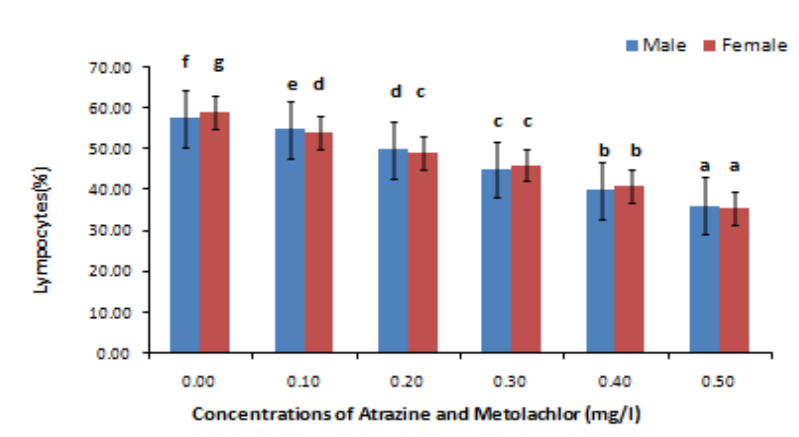

Bars with the different superscripts are significant $(p<0.05)$

Figure 7 Comparative values of Lympocytes in C. goriepinus juveniles exposed to Atrazine and Metolachlor.

with increasing concentrations of the chemical (Figures 4-6). Comparatively, the values of lymphocytes platelets and MCV in the exposed fish indicated a significant reduction that was more noticeable in female than the male fish (Figures 7-9). The values of $\mathrm{MCH}$ were lower in female fish than the male especially at higher concentrations of the chemical (Figure 10). The MCHC 


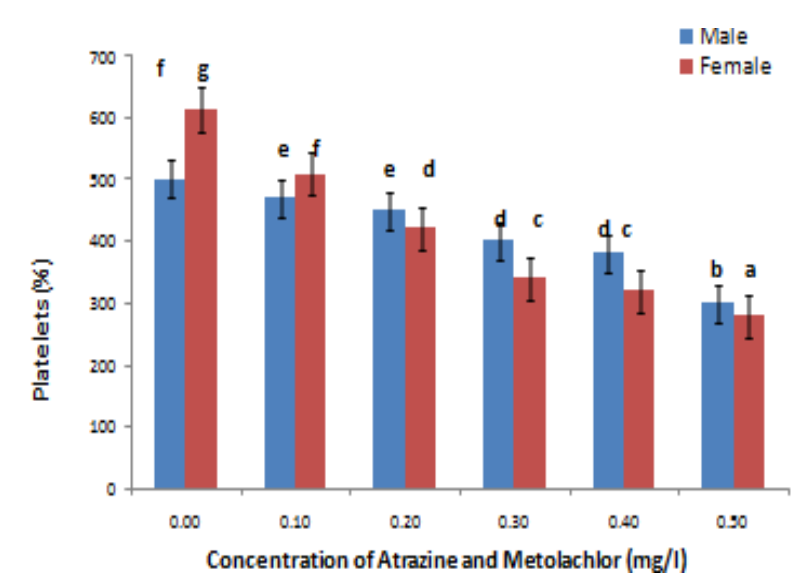

Bars with the different superscripts are significant $(p<0.05)$

Figure 8 Comparative values of Platelets in C. goriepinus exposed to Atrazine and Metolachlor.

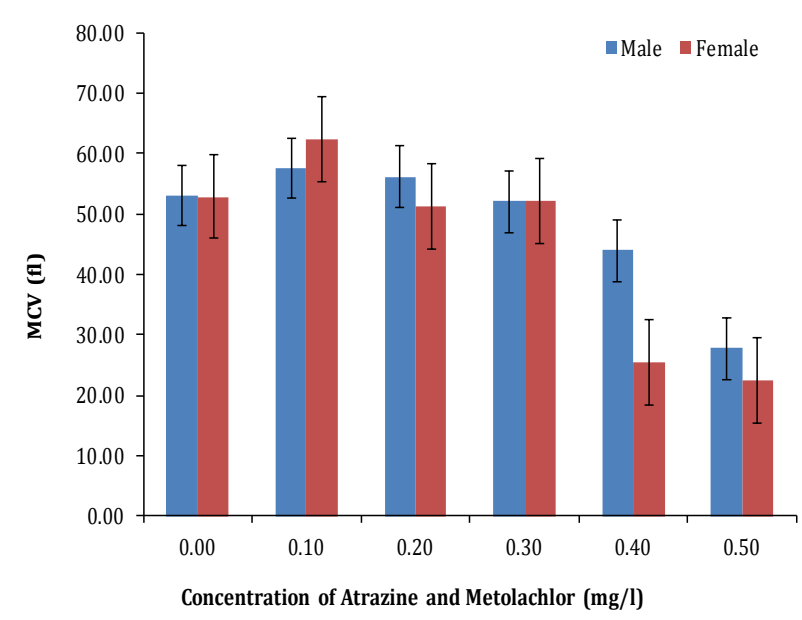

Bars with the different superscripts are significant $(p<0.05)$

Figure 9 Comparative values of MCV in C.gariepinus juveniles exposed to Atrazine and Metolachlor

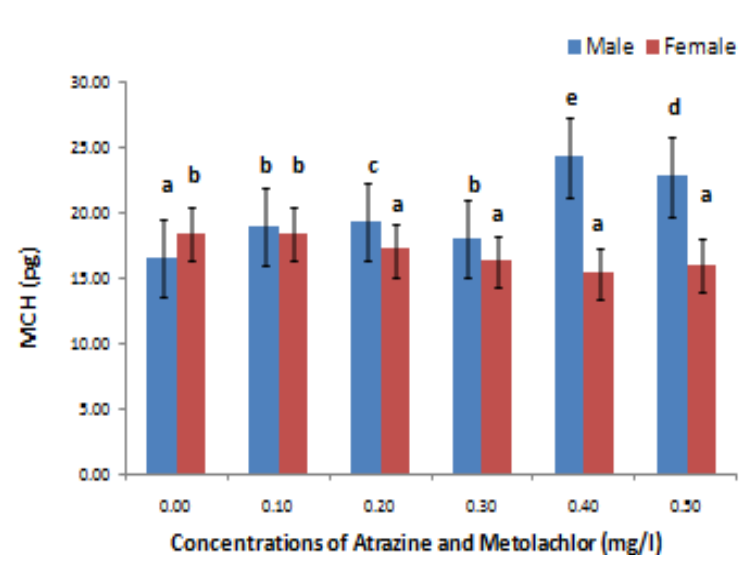

Bars with the different superscripts are significant $(p<0.05)$

Figure 10 Comparative $\mathrm{MCH}$ values in $\mathrm{C}$. goriepinus juveniles exposed to Atrazine and Metolachlor.

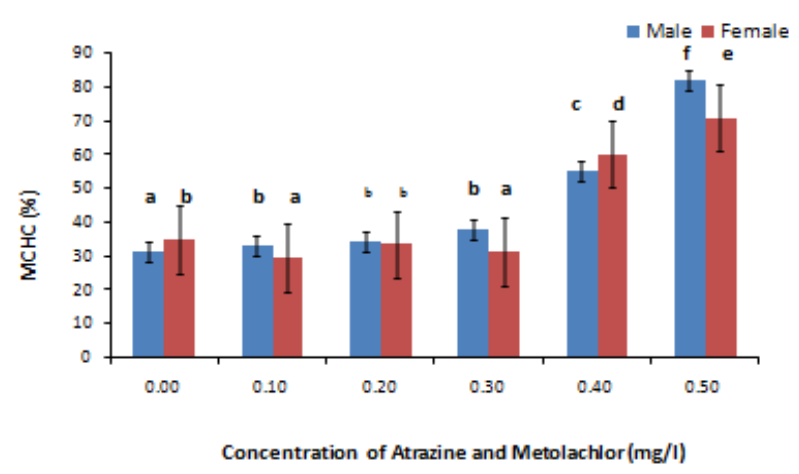

Bars with the different superscripts are significant $(p<0.05)$

Figure 11 Comparative valus in $\mathrm{MCHC}$ of $C$. goriepinus exposed to Atrazine and Metolachor.

values were lower between 0.00 to $0.30 \mathrm{mg} / \mathrm{L}$ of the chemical, higher values were recorded between 0.40 and $0.50 \mathrm{mg} / \mathrm{l}$ of the chemical in both male and female fish (Figure 11).

\section{Discussion}

Changes in hematological parameters might have been brought about by combined atrazine and metalochlor as an anemic condition due to decreased synthesis of $\mathrm{Hb}$ and RBC number in hemopoietic organs. The reduction of RBC is mainly due to development of hypoxic condition during the treatment which intern leads to increase in destruction of RBC or decrease in rate of formation of $\mathrm{RBC}$ due to non-availability of $\mathrm{Hb}$ content in cellular medium [29]. The damaging of toxicant on erythrocyte may be secondary, as resulting from a primary action of toxicant on erythropoietic tissues on which there exists a failure in red cell production and or due to increase in the erythrocyte destruction [30]. Moreover, Adhikari [31] also reported that the RBC count and $\mathrm{Hb}$ concentration decrease may depend on, sex as observed in this study.

Sex differences in haematology of fish would constitute a plausible physiological mechanism behind behavioral differences between males and females in response to chemicals. Evaluation of influence of sex response is necessary in assessment of fish haematology. In the evaluation of the blood parameters of Clarias batrachus exposed to toxins the authors [32,33] found that males always had appreciably higher PCV values than the females and advised that during blood analysis, parameters should be separated on the basis of sex to avoid attributing sex related variations to other elements. This statement agrees with that of Spirita [34] who reported wide variations in $\mathrm{Hb}, \mathrm{PCV}$ and RBC indices between male and female zebra fish exposed to akyl benzene. Furthermore, in this study, disparity was recorded in the values of the various blood parameters between male and female in the fish exposed to atrazine and metalochlor. Similar observations had been made in other fish species and were attributed to intrinsic factors not sex $[35,36]$.

Our study revealed sex differences between all groups of exposed fish. The male fish showed a wide range in most of 
the parameters than female fish. This also have been reported by Akinrotimin [37] who found sex differences between male and female Sarotherodon melanotheron exposed to acclimation . Also, Gabriel et al. [21] found a high erythrocyte count in males than females of of Clarias gariepinus exposed to cypermethrin in the laboratory. This appears to be related to activity of sexes, male being more active and also appears to be associated to be more responsive to the chemical. However, the result obtained in this study indicates that after exposure to the chemical, the female fish consistently had higher values of $\mathrm{Hb}, \mathrm{RBC}, \mathrm{PCV}, \mathrm{WBC}$, neutrophils, monocytes and lymphocytes than the males, but the reverse was the case with platelets, $\mathrm{MCV}, \mathrm{MCH}$ and $\mathrm{MCHC}$. It appears then that the males are more responsive to the stress of chemical exposure than the females. These differences on hematological data recorded in this study depend on different needs of oxygen in male and female fish, especially in reproduction period. For instance, the values of $\mathrm{Hb}$ are higher in male than female, while that of WBC is higher in female than male. Higher values of some hematological indices for male than females are caused by varying activity of erythropoietin. Testosterones, the male sex hormones, stimulate its production while estrogens, the female hormones, have a suppressing effect on erythropoietin, which is responsible for of some blood parameters [38]. This conclusion is in line with other authors $[39,37]$ who observed the same trend in fish exposed to different types of stressors in culture medium.

Exposure of $C$. gariepinus to combined effects of atrazine and metalochlor indicated a consistent elevation in the values of WBC which is more pronounced in female fish than the males. The result agrees with the report of Anyanwu [12] in exposure of black jaw tilapia to different salinity gradients. Increase in WBCs count occurred as a pathological response since these WBCs play a great role during infestation by stimulating the haemopoietic tissues and the immune system by producing antibodies and chemical substances working as defense against infection [40]. The higher values of WBC in the female fish indicated that is WBCs in the system

\section{References}

1 Chindah AC, Braide AS, Oraye O (2008) Response of Sarotherodon melanotheron in the Niger Delta Wetland, Nigeria to changes in $\mathrm{pH}$. Revista UDO Agricola 8: 143-153.

2 Akinrotimi OA, Edun OM, Makinde OO (2015) Seasonal variation of heavy metals in selected sea foods from Buguma and Ekerekana creeks, Niger delta. International Journal of Innovative Studies in Aquatic Biology and Fisheries 1: 46-53.

3 Chindah AC (2004) Toxicity of Cypermethrin to Tilapia guineensis juveniles. Journal of Agric. Biotech Env 2: 60-66.

4 Nestmann ER, Lee EGH, Muller JC, Douglas GR (1980) Mutagenicity of constituents identified in pulp and paper mill effluents using salmonella. Mutat Res 79: 203-212.

5 Ellis RJ, Vande HMR, Smith E (2003) In vivo and in vitro assessment of the androgenic potential of a pulp and paper mill effluent Environ. ToxicolChem 22: 1448-1456.

6 Makinde OO, Edun OM, Akinrotimi OA (2015) Comparative Assessment of Physical and Chemical Characteristics of water in Ekerekana and of the fish respond immediately to the change in medium due to xenobiotic transformation, an indication that female fish is able to cope with the toxic stress more than the males.

Furthermore, some of the haematological traits indicative of stress-coping style appear to be influenced by sex as differential count levels is higher in male fish than the female, an indication of aggressive behavior noticeable in male fish when compared to the female. Our analyses revealed striking observation that sex-influenced hematology in C. gariepinus exposed to toxicants exhibited generally similar expression behavior in response to toxicological perturbations. Intriguingly, the extent of these alterations in blood indices also increased with the increasing concentrations of the chemical. As this will determine the severity or susceptibility of fish to a given toxico-pathological state, suggesting the importance of sexbiased haematological parameters in playing active roles in predicting physiological functions of the fish.

\section{Conclusion}

The present investigation showed that combined Atrazine and metalochlor caused noticeable alterations in the haematological parameters in $C$. gariepinus which suggest that the pesticide may weaken the immune system and result in severe physiological problem and ultimately lead to the death of fish. Taken together, these findings support the view that distinct physiological stress-coping styles are present in teleost fish, and influence its haematological indices. This study revealed that the sex of fish may exert some degrees of influence on some of hematological characteristics $C$. gariepinus and hence the need to reckon with these factors in the assessment and reporting of the hematological indices of this fish species at the resting state or in the face of any stressor such as chemicals.

Buguma Creeks, Niger Delta, Nigeria. Journal of Environmental Protection and Sustainable Development 2: 66-73.

7 Chindah AC, Hart Al (2000) Occurrence and distribution of epi fauna and in-fauna community in shallow mangrove wet land in the tropical West African Region. Afr J Env Stud (1\&2): 76-83.

8 Gabriel UU, Anyanwu PE, Akinrotimi OA (2007) Hematological Profiles of Black-Chinned tilapia (Sarotherodon melanotheron) from Buguma Creek. Niger Delta Agricultural JournaL 2: 387.

9 Akinrotimi OA, Abu OMG, Ansa EJ, Edun OM, George OS (2009) Haematological responses of Tilapia guineensis to acute stress. International Journal of National and Applied Sciences 5: 338-343.

10 Akinrotimi OA, Uedeme-Naa B, Agokei, EO (2010) Effects of acclimation on haematological parameters of Tilapia guineensis. Science World Journal 5(4): 1-4.

11 Beyer J, Sandvik M, Hylland K, Fjeld E, Egaas E, et al. (1996) Contaminant accumulation and biomarker responses in flounder (platichthys flesus L.) and Atlantic cod (Gadus Morhua L.) exposed by carrying to polluted sediments in Sorfjorden, Norway. Aquat. Toxicol 36: 75-98. 
12 Anyanwu PE, Gabriel UU, Anyanwu AO, Akinrotimi OA (2007) Effect of salinity Changes on Haematological Parameters of Sarotherodon melanotheron from Buguma Creek Niger Delta. Journal of Animal Veterinary Advances 6: 658-662.

13 Gabriel UU, Uedeme-Naa B, Akinrotimi OA (2011) Pollutant induced altered behaviours in fish: A review of selected literature. Journal of Technology and Education in Nigeria (JOTEN) 16: 9-23.

14 Akinrotimi OA, Agokei EO, Aranyo AA (2012) Changes in haematological parameters of Tilapia guineensis exposed to different salinity levels. Journal of Environmental Engineering and Technology 1: 4-12.

15 Gabriel UU, Ezeri GNO, Opabunmi OO (2004). Influence of sex, source health status and acclimation on the haematology of Clarias gariepinus. African Journal of Biotechnology 3: 463-467.

16 Hrubec TC, Cardinale JL, Smith SA (2000) Haematology and plasma chemistry reference intervals for cultured tilapia Oreochromis hybrid. Vet Clin. Pathol 29: 7-12.

17 Gabriel UU, Akinrotimi OA, Eseimokumo F (2011) Haematological responses of wild Nile tilapia Oreochromis niloticus after acclimation to captivity Jordans. J Biol Sci 4: 225-230.

18 Nte MD, Hart AI, Edun OM, Akinrotimi OA (2011) Effect of industrial effluents on haematological parameters of Black jaw tilapia Sarotherodon melanotheron. Continental Journal of Environmental Science 5: 29-37.

19 Kumar M, Sunnita HSC, Mishra FD (2005) Toxicity of detergent effluent to fish Pontius sophore. Journal of Tissue Research 1: 41-48.

20 Kori-Siakpere O, Ake JEG, Avworo UM (2006) Sublethal effects of Cadmium on some selected haematological parameters of Heteroclarias (A Hybrid of Heterobranchus bidorsalis and Clarias gariepinus). Int J of Zoological Research 2: 77-83.

21 Gabriel UU, Akinrotimi OA, Ariweriokuma SV (2012) Alterations of selected electrolytes in organs of African catfish, Clarias gariepinus treated with cypermethrin. Advances in Students Research 2(1): 53-60.

22 Larsson A, Hanux C, Sjobeek ML (1985) Fish physiology and metal pollutions; results and experiences from laboratory and field studies. Ectoxicology and Environmental Safet 9: 250-281.

23 Kori-Siakpere O, Ikomi U (2011) Alterations in some haematological parameters of the African Snakehead Parachanna Africans exposed to Cadmium. Nat Sci Biol 3: 29-34.

24 Ogundiran MA, Fawole OO, Adewoye SO, Ayandiran TA (2010) Toxicological impact of detergent effluent on juveniles of African catfish (Clarias gariepinus). Agriculture and Biology Journal of North America 1: 330-342.

25 Vani T, Saharan N, Mukherjee SC, Ranjan R, Kumar R, et al. (2011) Deltamethrin induced alterations of haematological and biochemical parameters in fingerlings of cala catla (Ham) and their amelioration by dietary supplement of vitamin C. Pestic Biochem Physiol 101: 16-20.
26 Blaxhall PC, Daisley KW (1973) Routine haematological methods for use with fish blood. Journal of Fish Biology 5: 771-781.

27 Seiverd CE (1964) Haernatology for medical technologists. Lea and Febiger Philadephia 946

28 Rusia V and Sood SK (1992) Routine haematological test In: Medical laboratory technology Mukerjee KL (edition) Tata McGraw Hill Publishing Company Limited.

29 Chen X, Yin D, Hu S, Hou Y (2004) Immunotoxicity of penta chlorophenol on macrophage immunity and IgM secretion of the crucian carp (Carassius auratus). J BulL Environ Contam Toxicol 73: 153-160.

30 Mgbenka BO, Oluah NS, Umeike I (2003) Effect of Gammalin 20 (Linndane) on differential white blood cells count of the African catfish Clarias albopunctatus. Bull Environ Contam Toxicol 71: 248-254.

31 Adhikari S, Sarkar B, Chatterjee A, Mahapatra CT, Ayyappan S (2004) Effect of cypermethrin and carbofuran on certain hematological parameters and prediction of recovery in a freshwater teleost, Labeo rohita (Hamilton). Ecotoxicol. Environ Saf 58: 220-226.

32 Gabriel UU, Akinrotimi OA, Eseimokumo F (2011) Haematological responses of wild Nile tilapia Oreochroimis niloticus after acclimation to captivity. Jordan Journal of Biological Sciences 4: 223-230.

33 Summarwas S, Lall D (2013) Effects of toxins on blood plasma of Clarias batrachus. Indian Journal of Fundamental and Applied Life Sciences 3: 133-136.

34 Spirita SV, Kanagapan M, Sam SDS, Auila VR (2015) Studies on the toxicity of akylbenzene sulphonate to Zebra fish. Danio rerio. Journal of Entomology and Zoology Studies 3: 204-207.

35 Shahi J, Chauhan S, Singh A (2013) Comparative study on the haematological effect of synthetic and plant origin pesticides on fish Channa ponctatus. Indian Journal of Natural Products and Reserves 4: 48-53.

36 Omer SA, Elobeid MA, Fouad D, Daghestani MH, Al-Olayan EM, et al. (2012) Cadmium bioaccumulation and toxicity in Tilapia fish (Oreochromis niloticus). Journal of Animal and Veterinary Advances 11: 1601-1606.

37 Akinrotimi AO, Gabriel UU, Anyanwu PE, Anyanwu AO (2007) Influence of sex, Acclimation Methods and Period on Haematology of Sarotherodon Melanotheron (cichilidae). Research Journal of Biological Sciences 2: 348-352.

38 Trojan S (2003) Medical physiology, Grada Publishing. Prague, 771 $\mathrm{pp}$ (in Czech).

39 Gabriel UU, Anyanwu PE, Akinrotimi OA (2007) Effect of Freshwater Challenge on the Blood Characteristics of Sarotherodon melanotheron. Agricultural Journal 2(3): 388-391.

40 Lebelo SL, Saunders DK, Crawford TG (2001) Observations on blood viscosity in striped bass, Morone saxtilis (Walbaum) Associated with fish Hatchery conditions. Kansa Acad Sci 104: 183-194. 